UDC 82.09-3

Vladislava Gordić Petković

University of Novi Sad, Serbia

\title{
THE HOME OF THE CHARACTER: REMARKABLE HEROINES WITHIN THEIR FICTIONAL SETTINGS
}

\begin{abstract}
This paper examines various narrative strategies which serve to represent characters within their historical, social or political settings. Authors belonging to different literary, historical and social backgrounds such as Geoffrey Chaucer, Sarah Waters and Douglas Coupland are chosen so as to provide a multicultural context for the analysis. Where the home of the character is, and how the setting affects their progression and development, are some of the issues discussed in the paper.
\end{abstract}

What has traditionally been central to theories of character is the concept of identification, which mediates between literary character as a formal textual structure and the reader's investment in it (Frow 1986: 243). What readers invest is interplay of inference, deduction and interpretation. However, this interplay largely depends on the process of narration, conducted by the omniscient narrator or a character involved in the story, and on the proper construction of the story's setting.

This paper attempts to explain the ways female characters act within their settings. We focus upon the works of those writers, men and women, classic and modern, who treat their characters either as functional devices of the plot or as fully shaped personalites dealing with their milieu. Our aim is to show both the psychological impact of the setting upon the character and the functional role of the character in portraying the setting.

Characterization is often vaguely described as "the depicting... of clear images of a person", his or her "actions and manners of thought and life", or as the portrayal of someone's "nature, environment, habits, emotions, desires, instincts" (Thrall and Hibbard, pp. 74-75). According 
to Aristotle, artists imitate people involved in action, not independent existents of the text. The formalist and structuralist critics of the twentieth century also argue that a character is functional and simply doing what the story requires her or him to do. Some structuralist critics have gradually moved away from the functional approach to character, claiming, as is the case with Tzvetan Todorov, that a narrative text can either be plot-centered (apsychological), or character-centered (psychological), where the former focuses on the plot and the latter focuses on the character. Roland Barthes gradually shifted from the functional view of character, adopted in the sixties, to a psychological one, embraced late in the seventies, admitting that at that in some narratives characters play a more significant role than elsewhere.

The categories of masculinity and femininity have recently emerged as discursive constructs and socially determined categories important for character analysis. Whether a female is always associated with the submissive and passive and a male characterized as dominant and assertive is to be shown in our analysis of literary texts coming from various historical, social and literary contexts.

\section{Characters in their own utopia}

One of the most refined women's voices articulated in recent Serbian fiction, Mirjana Novaković challenges and redefines issues of female recluse and the estranged society. Her literary career started with The Danube Apocrypha, two stories united within a gothic frame: one of them is The Gospel According to A Thirsty Woman, set in a nameless city, distantly resembling Belgrade with its street plan and traffic connections, but otherwise devoid of flair and identity. The story tells of social and religious turmoil in the near future, and a bitter and long struggle with an enemical, Orwellesque social setting.

The Gospel According to A Thirsty Woman casts a bleak and sarcastic dystopian perspective upon a society which advocates equality but actually encourages its citizens' total loss of identity; personal or proper names are forbidden whereas plastic surgery and genetic modification are advised so that individuals might remove all bodily marks and character traits that prevent them from fitting into the homogenous community. This dismal state, dubbed Open Society, requires self-sufficiency and the dissolution of family ties, but is confronted with a group of female misfits who celebrate a nameless goddess and the religious creed of an unquenchable thirst 
V. Gordić Petković: The Home of the Character: Remarkable Heroines...

for knowledge. The thirst in which they trust is a travesty of the Biblical motive, as their deity is an inverted parallel to Christ: the followers of the cult of Her are not meant to be peaceful and content once they have accepted a religion. The first and foremost thing the thirsty women fight for is a name. The identification of the character preceeds the search for one's identity and thus in the society of the nameless the awakening starts with confiding your name to your soulmates.

The all-male death squad called the Human Rights Representatives gets dangerously close to eradicating the tribe of the thirsty, but the creed persists, owing to Catherine, the anonymous female narrator whose name we learn at the very end, after she wrestles with the demons within and without and earns the privilege to spread the word of the Thirsty Woman. Instead of committing suicide after she betrayed her goddess, Catherine decides to live and tell: "Seemingly it makes no sense to take my leave without leaving an explanation or a message behind." (Novaković, p. 48). The story she prepares to tell is the one we have been listening to all along, both a fable and a testimony. Thus the word of the character defies an enemical social and political setting.

Although Novaković has never publicly sided with the feminist movement, the plot and the characters from The Gospel take us back to feminist texts such as Charlotte Perkins Gilman's Herland, and the belatedly acclaimed The Yellow Wallpaper. Gilman never thought of herself as a feminist either; it was her standpoint of social Darwinism that led her to criticise society as androcentric and male-oriented at its core. Her firm conviction that women should be a part of the economic order of the world is advocated in various ways, both in her Utopian fiction about a land of females, and the gothic story of female frustration and liberation that has become a true feminine gospel.

\section{The haunted home}

Novakovićs alternative history of female networking parallels the seclusion and liberation of Charlotte Gilman's nameless protagonist in The Yellow Wallpaper. This story deals with the social resistance to male domination through a testimony of a female patient, who is both captured and being cured by her husband. The Yellow Wallpaper is set in a collonial mansion which has been empty for years, perceived as "queer" and "haunted" by the heroine, and her mixed feelings of awe and 
enchantment echo the reaction to the setting in a typical gothic novel. Her room resembles a scary version of Virginia Woolf's "a room of one's own", a room which should be a woman's prerequisite for artistic creation, not physical incarceration. With its barred windows and iron bed, the room resembles prison and mental asylum: this is not a place to nurse the ailing or control the criminal, but rather a bleak quarter which induces sickness, derangement and madness.

The story gives voice to rebellion against patriarchal society, but it also deals with highly ambivalent issues of maternity and female creativity, seeing these two as inevitably clashing. The main character's fixation upon the yellow wallpaper could be interpreted both as her rebellion against patriarchal society and male-centered writing. The story dramatizes the concept of female captivity, the house and the room symbolizing a woman's body and her wish to break free from its restrictions. Being treated as an invalid and a prisoner, the heroine has to recover her freedom first. The vision of a female Utopia as a rescue for all subdued women is yet to come, after the personal conflict is resolved.

The female protagonist is denied reading and writing, allegedly for her own good, the same way the Open Society denies the right to feel and think. Therefore her fascination with the ugly wallpaper turns into an obsession with a woman captured behind it. The namelessness of the protagonists in the stories by Novaković and Gilman signals that the bitter struggle for equality starts with acquiring identity and adopting a name. It is only then that a woman can join hands with other women.

\section{The house divided}

According to an analysis by evolutionary psychologists presented recently in The Guardian, the despicable acts of Count Dracula, the unending selflessness of Dorothea Brooke in Middlemarch and Mr Darcy's personal transformation in Pride and Prejudice helped to uphold social order and encouraged altruistic genes to spread through Victorian society. Their research suggests that classic British novels from the 19th century not only reflect the values of Victorian society, they also shaped them.

The psychologists, led by Joseph Carroll at the University of Missouri in St Louis, claim that the novels from the period "extolled the virtues of an egalitarian society and pitted cooperation and affability against individuals' hunger for power and dominance", citing the examples of George Eliot's Dorothea Brooke, who turns her back on wealth to help 
V. Gordić Petković: The Home of the Character: Remarkable Heroines...

the poor, and Bram Stoker's Count Dracula, who represents aristocratic dominance at its worst and asserting prestige by taking people over and absorbing their life blood.

What the team of evolutionary psychologists did was to apply Darwin's theory of evolution to literature by asking 500 academics to fill in questionnaires on characters from classic Victorian novels. The respondents were asked to define characters as protagonists or antagonists, rate their personality traits, and comment on their emotional response to the characters. They found that the leading characters mirrored the cooperative nature of a society, whereas individual urges for power and wealth were suppressed for the good of the community. It seems that in Victorian novels, dominant behaviour is stigmatised and the antagonists obsessed with ambition lack a cooperative nature and pro-social behaviour.

A few characters were judged to have both good and bad traits, such as Heathcliff in Emily Bronte's Wuthering Heights and Jane Austen's Mr Darcy. The conflicts they demonstrate reflect the strains of maintaining such a cooperative social order. The researchers believe that novels have the same effect on society as oral cautionary tales of old. "Just as huntergatherers talk of cheating and bullying as a way of staying keyed to the goal that bad guys must not win, novels key us to the same issues," said Christopher Boehm, a cultural anthropologist at the University of Southern California. "They have a function that continues to contribute to the quality and structure of group life."

Studies of Victorian novels have substantially changed throughout the decades. They are no more associated with simplistic and reductive models of morality or famous but elusive "Victorian values", or condemned as racist, imperialist or misogynist. The Victorian novel is seen as complex as the culture it comes from, and the Victorians are seen more empathetically.

Wuthering Heights is a novel in which setting and mood are closely intertwined, to the extent that the characters become helpless in the face of nature and their own uncontrolled emotions. The novel focuses upon the dynamic and often turbulent relationship between the passion and freedom of the mansion called "Wuthering Heights" and the socially structured conventionality of "Thrushcross Grange". Being large and isolated, also dark and foreboding at times, both houses are reminiscent of a gothic novel. They both depict isolation and separation, each creating its own galaxy with its house rules. 
"Wuthering Heights" is perched on a high ridge, overlooking a wasteland, inhabited by harsh and gloomy characters who made it a world of passion and ferocity long before it became the property of the demonic lover and passionate avenger, Heathcliff. Throughout the novel, "Wuthering Heights" is the stage of both unrequieted and unconditional love, violence, brutality, child molestation, and inexplicable greed. While suggesting the extreme states of mind we encounter in the novel, the name of the mansion also marks the sense of aspiration to something supreme. On the other hand, "Thrushcross Grange" is a symbol of social institutions and conventional values, the possibility of freedom and happiness for Catherine and her road towards both femininity and social status. She tries to love both the wild Heathcliff and the mild Edgar Linton, and tries to make both houses her home.

The first indication of Heathcliff's savage personality is found in the opening chapter of the novel when Heathcliff's dogs attack Mr. Lockwood and are called "a brood of tigers" and "fiends". Heathcliff growls in unison with their snarls, easily and uncontrollably displaying his animal essence, a society reject even after turning into respectable land owner. Civilized only outwardly, Heathcliff remains demonic, and the increase of wealth and power never changes him substantially. His violent images and use of hyperbole express an impetuous will that cannot accept opposition. His rhetoric hardens as it gathers momentum towards a language of absolute imperatives, his logic dependent on a refusal to admit any compromise with passion, any form of mediocrity.

The distinctions between "Thrushcross Grange" and "Wuthering Heights" (between Edgar and Heathcliff) parallel those between Catherine and Heathcliff. The isolation of "Wuthering Heights" represents the isolation of Catherine's heart; the warmth and security of the Grange represent the domesticity and status that Catherine desires. The two men in her life have turned into exact replicas of the power of the respective houses they live in.

\section{Chaucer revisited}

In Canterbury Tales there is no plot for the characters to act in, so they cannot be considered agents; there are no houses to represent their moods and feelings, so they cannot be symbolically connected to their setting. Chaucer's characters do not engage in any kind of activity except story- 
V. Gordić Petković: The Home of the Character: Remarkable Heroines...

telling. Their only acts are speech acts, and the lack of action hampers any development or change in their nature. This is partly because the concept of a developing character is not common in the literature of Chaucer's time; traditional story-telling calls for no growth of character, no progressive or temporal change. Although the portraits of Chaucer's characters cannot indicate a change in mood or the flow of thought, they are still rich in detail and very vivid, owing to direct narrative statements about the characters which name personal traits and inform us about their physical appearance, habits or biography. The reader is faced with an abundance of detail, drawn either from the narrators' outer perceptions or from their omniscient glimpses into the interior of the other characters. Thus the what, denoting a particular narrator's focus and interest, can be subdivided into personal traits (whether physical or psychological), habits and biographical facts. The how or Chaucer's way of characterization can be described as more rhetorical than psychological. Nothing is shown in action, everything is told, either by the omniscient author, or by the characters themselves.

The structure of Canterbury Tales is paratactic, since the work juxtaposes individual portraits and tales connected only by the pilgrimage motif. The Canterbury Tales provide their reader with a representative panorama of fourteenth century society, starting from the top of the social scale and the highest point of the moral scale, going downward.

The two female characters in Canterbury Tales are not quite typical of their class and status. The Prioress's grace, elegance, affectation of speech and manners, as well as the Wife of Bath's five marriages, apparently do not fit into mediaeval stereotypes. Chaucer depicts a prioress in terms and traits borrowed from the medieval romance, whereas an artisan woman from Bath resembles a matriarchal goddess. Chaucer contrasts feelings embodied in the Prioress with the senses of the Wife of Bath. While the former embodies fastidious sensibility, the latter is the pole of elemental vitality. The Prioress represents a woman who has submitted to the institution of the Church, trying to fit her temperament into it, but she also subtly violates the laws of her order by keeping pets, overdressing and taking on a pilgrimage. Opposed to Eglentine's passivity and subtlety are the Wife of Bath's outspokenness, aggressive demonstration of her instincts, appetites and will to power. The Wife of Bath makes the institutions of church, pilgrimage and marriage serve her temperament: her radix trait is an uninhibited appetite for physical love and travel, which is seen in the first word in her prologue, experience, which is also the key to her morals and values. Another code of her personality is the desire 
for mastery, which is the dominant motif of her tale. The Wife of Bath's doctrine of marriage is based on female supremacy, never stated openly but rather functioning as a reaction to the traditional view of marriage imposed by the church fathers and common law.

Chaucer manipulates the mode of medieval romance in the characterization of his heroines: while the Prioress physically resembles a romance heroine, the Wife of Bath uses a romantic setting in her story of the magical hag and the rapist. Both ways of using romance are tinged with irony. A prioress is not expected to look romantic, whereas the Wife of Bath uses the romantic setting in order to disguise the idea of female supremacy. Her prologue and her tale are two versions of one story: both Jankyn and the rapist knight treat women with violence, and both are taught to do better than that; they win the woman's kindness and affection once they come round to her way of thinking.

The Wife of Bath is well acquainted with Holy Scripture, and she deconstructs it in the greatest part of her prologue, picking and choosing the quotations and episodes which support her way of thinking. Her skillful handling of Scripture in the comic debate on marriage shows that she is a knowledgeable woman, but the issues of religion bring up another substantial contrast between the Wife of Bath and the Prioress: while the Wife of Bath embodies empirical knowledge of facts, the Prioress embodies blind religious faith. The latter is a person of limited mentality, credulous enough to accept naively a legend of a horrible murder of a child committed by Jews, and to recount it. No matter how cruel her story might seem, it is mostly an act of worship. This devoutness and piety is something the worldly Wife of Bath is incapable of.

While the Wife of Bath posseses excessive sex-appeal, the Prioress is feminine, generally an embodiment of feeling. Her suppressed maternal instincts turn to the nearest object upon which she can lavish her natural affection - to pets. Chaucer vividly describes her appearance, her habits, likes and dislikes, but we learn practically nothing of her background. What we get are just traits and habits, but no facts! Does this lack of biographical fact suggest that the Prioress is a lifeless, unreal being? And, since we have a Molly-Bloom-like story of husbands and marriages, could we make another opposition, and say that the Prioress symbolizes an ideal versus the real woman, who is deliberately called Wife of Bath?

For the Wife of Bath, her tale is her own setting. Much has been written about the "legendary tale of wonder" dealing with a knight who has to pay dearly for doing wrong to womankind, but we cannot say that 
the problems of the narrative have been solved. Some passages in the Wife of Bath's tale admirably befit the teller, but her heroine is not Alison in disguise. We can compare Alison's methods of winning sovereignity with those of the loathly lady in her tale, but Chaucer's character lacks reasonableness and persuasiveness of the loathly lady. The Prologue tells us something of Alison's tactics before and after marriage: by her shrewishness she reduced her husbands to complete submission and obedience, all except the fifth, the former "clerk of Oxenford". Her struggle to subdue her partners does not make her a feminist figure, rather a figure of fun, since the issue of female supremacy was taken to be either blasphemous or ridiculous, and Chaucer chooses the latter option.

The Wife of Bath's Tale consists of three sections: in the first, a knight from King Arthur's court rapes a girl and is condemned by the Queen to find within a year and a day the answer to the question, what is the thing that women most desire. The second section describes the knight's encounter with an ugly hag who offers to solve the riddle on condition he should do whatever she asks: she demands marriage in turn for the answer, which is "sovereignty" (sovereynetee). The final part of the story shows the knight in dismay on his wedding night, when his wife offers him the choice between having an ugly but faithful spouse or a beatiful but faithless one. He yields the choice to her, and seeing her sovereignty acknowledged, she promises to be both faithful and beautiful.

The riddle motive is closely connected with the theme of sovereignty. The old hag poses a challenge to the protagonist. Her very existence is a contradiction: she is a puella senilis, both fair and loathly, both young and old, and she makes demands falling outside the pale of the tolerable, if not of the possible. The sovereignty she demands means domestic rule, but she needs the man, her counterpart in order to settle to her task and her nature. Thus Chaucer sends the message of contradictions united in greatness - the message more complex than his seemingly simple techniques of characterization.

\section{The world of the homeless: Generation X}

Douglas Coupland's novels deal with an "accelerated culture": his characters are desperately trying to cope with rapid material changes in everyday life and lame spiritual insights offered to account for them. Focused upon the mass cultural phenomena (such as pop icons or the fallout of yuppies) 
and those genuinely tragic (such as high school shootings), Coupland is also interested in technology as a substitute for the divine, so that two of his novels present lives and opinions of Silicon Valley computer experts (Microserfs) and the offspring of the Google age (JPod).

Coupland's characters share their creator's awareness that the world changes much faster than human perspectives of it. Lost and confused, underemployed and overeducated, Coupland's twentysomethings find their mantras in pop songs and seek salvation in awkward possessions. Charming and sensitive Claire of Generation $X$, one of the most remarkable and sensitive female characters Coupland has ever written, goes to incredible lengths to get such a bizarre thing as a collection of racks of antlers: dozens of them lie tangled in her flat, in "the room that technically ought to have been the dining room instead of an ossuary that scares the daylights out of repairpersons come to fix the appliances" (Coupland 1991: 85). Claire even places ads in the local paper, presenting herself as an artist, and "nine times out of ten the respondent is a woman named Verna, hair in curlers, chewing nicotine gum", a woman who wants to get rid of the things left behind by her ex.

Coupland's characters indulge in endless contemplation of their anomie, mostly seeking refuge in platonic friendships, cartoon heroes, and funny memories. Families and relatives are usually estranged or on bad terms. Abe, one of the Silicon Valley programmers from Microserfs, claims to have come from "one of those 'zero kidney' families" - the family which made the agreement that if one of its members needed a kidney, they would react with: "Well, sorry... Been nice knowing you." (Coupland 1995: 190). Although jaded and cynical, this young man earnestly mourns the lost values. Rereading his favourite Tin Tin books, Abe notices that the Boy Detective's life lacks "religion, parents, politics, relationship, communion with nature, class, love, death, birth" (Coupland 1995: 191), and admits that he is curious about this either invisible or non-existent content.

The recurrent pattern of "the family of friends", borrowed from sitcoms and soap operas, serves the purpose of creating safe surroundings for the unstable young men and women. Coupland has suggested on various occasions that inspiration for some of his novels might have come from teenage soap operas of the eighties such as Melrose Place. The self-confessed computer nerds of Microserfs call themselves addicts of the series: "We like to pretend our geek house is actually Melrose Place." (Coupland 1995: 65). Shopping malls and pop music have been attached to the ideological framework of Coupland's novels almost naturally. 
V. Gordić Petković: The Home of the Character: Remarkable Heroines...

Such cultural background of the characters ranging from the not-quitefabulous threesome in Generation $X$ to the star-crossed teenage spouses in Hey, Nostradamus! might make them look two-dimensional and devoid of depth. However, Coupland's protagonists show some signs of progress or change, in spite of the fact that they never manage to change at the rate the accelerated world requires. Hey, Nostradamus! shows how painful and ineffective changes can be. A little before her tragic demise in the shooting in a Vancouver high-school cafeteria, pregnant and secretly married Cheryl Anway writes on her school binder the words "GOD IS NOWHERE GOD IS NOW HERE", and thus anarchy and faith are put together with a little help coming from unreliable linguistic signs, language being only one battlefield of many. In their post-trauma or post-mortem quest for truth, the departed Cheryl, her loving husband Jason, Jason's religious father Reg and Jason's hopelessly loyal girlfriend Heather tell stories of paranoia, angst or religious zeal, desperately trying to untangle their lives. Misguided and shattered, they cope with their tragic losses the only way they can.

Although engaged in an in-depth analysis of profound crises and urgent problems, Coupland has often been accused of creating cartoonlike characters. His critics forget that the growth of the character which traditional novel calls for is somewhat impeded in the works of fiction which tend to be slowed by minute reflection or endless and often pointless discussions in the manner of either Raymond Carver or Quentin Tarantino, in the books and movies which, similar to Generation $X$, abound in static first-person narrative reports of an immobile reality.

Estranged and bizarre characters either float from one cheap thrill and weird hobby to another, or stay immobile, unwilling to take risks. What we find in Coupland's books is a genuine "technology" of character casting which is difficult to define. It is not easy to decide whether his protagonists suffer from inarticulateness, disillusionment and disenchantment, or emotional numbness.

\section{The Victorian home revisited}

In her four novels, Sarah Waters has dealt with lesbian characters positioned in history, either in the Victorian age as in her first three novels unofficially marked as "the Victorian trilogy", or in the Second World War setting of her latest book. Her recreation of a distant epoch 
has been urged by writing lesbians into the history of urban life and its various subcultures. Thus the title of her first novel Tipping the Velvet uses a cryptic jargon for physical intimacy in order to show that every period in history has its subterranean ethics of living. Her main heroine Nancy Astley, a young woman in the late 1880s who develops a passionate crush on another young woman, constructs her own lesbian identity owing to the twilight demimonde of late 19th century London with its paragons of virtue and lust. London plays a crucial role in this hybrid narrative of complicity and critique of Victorian society.

The view of London, and the metropolis in general, as an acting board and a visual show was rather common in the early nineteenth century: "We see in the 1820 s a society that regarded the metropolis as a stage on which to perform and witness its own civility, grandeur, and ebullience. The image of theatre is crucial to urban representation in the early nineteenth century, for it suggests not only entertainment and performance but also a relationship of distance and tentativeness between spectator and the action on the stage. The urban spectator of this period, whether writer or imagined subject, experienced the sights and people of the streets as passing shows or as monuments to be glimpsed briefly or from afar. This distance helped to obscure and control all that was seen, however arresting or unsettling, and it helped, too, to ensure that whatever did unsettle the spectator would not be understood as a symptom of some larger social disturbance." (Epstein Nord 1995:20).

Meeting the late $19^{\text {th }}$ century London and its artists, perverts, lesbians and socialists, Nancy creates her own creed. First of all, she has to win her territory: by the end of the nineteenth century, the streets of London had become accessible to women, in their role of charity workers, with a degree of freedom that previously had only been unquestionably granted to prostitutes. Nancy's evolution towards self-discovery and fulfillment runs parallel to her physical and metaphorical "journey against the current" towards and within the metropolis: from Whitstable to London and from the glittering West End theatres to the East End slums. On her journey of self-discovery, Nancy interacts with different social classes and experiments with dramatically different lifestyles. As a scholar specialised in Victorian literature, Waters was well aware of the theatrical elements in the urban representation: thus her heroine uses the city as her stage, obliterating the gender boundaries and bridging the gap between her authentic and stage identity.

The analysis of fictional works dating from a variety of epochs and literary contexts points out that female characters have something 
V. Gordić Petković: The Home of the Character: Remarkable Heroines...

in common. Whether it is a certain kind of inarticulatedness, a persistent air of disillusionment and disenchantment or a tendency to suffer from emotional numbness, it is not easy to determine. Victorian or postmodern, traditional or experimental, characters in the literary works we have tackled in this paper do establish a genuine female paradigm of traits.

\section{References}

Chatman, Seymour (1978). Story and Discourse. Ithaca: Cornell University Press.

Coupland, Douglas (1991). Generation X: Tales for an Accelerated Culture. New York: St. Martin's Press.

Coupland, Douglas (1995). Microserfs. London: Flamingo.

Gordić, Vladislava (1996). "Recent Approaches to the Theory of Character: Some Aspects of Characterization in Chaucer's Canterbury Tales". Novi Sad: Godišnjak Filozofskog fakulteta u Novom Sadu, XXIV: 99-103.

Epstein Nord, Deborah (1995). Walking the Victorian Streets. Women, Representation, and the City. Ithaca and London: Cornell University Press.

Frow, J. (1986). "Spectacle Binding: On Character" in Poetics Today. Vol. 7.(2): 227-250.

Malone, Kemp (1962). “The Wife of Bath's Tale”. The Modern Language Review, Vol. 57, (4) Oct. : 481-491.

Novaković, Mirjana (1996). Dunavski apokrifi. Novi Sad, Matica srpska.

Rimmon-Kenan, Shlomith (1983). Narrative Fiction. Routledge: London and New York.

Simple, Ian (2009). "Victorian novels helped us evolve into better people, say psychologists" in Guardian, 14 January. http://www.guardian. co.uk/science/2009/jan/14/victorian-novels-evolution-altruism

Thrall, William, and Addison Hibbard (1936). A Handbook to Literature. New York: The Odyssey Press.

Walkowitz, Judith R. (1992). City of Dreadful Delight. Narratives of Sexual Danger in Late-Victorian London. London: Virago.

Waters, Sarah (1999). Tipping the Velvet. London: Virago. 
